\title{
Rating DeConde's Stable of Diplomatic Historians
}

Alexander DeConde, ed., Encyclopedia of American Foreign Policy. Charles Scribner's Sons, New York, 1978.

$1138 \mathrm{pp}$., index.

BRADFORD PERKINS

The Encyclopedia of American Foreign Policy, a three-volume work edited by Alexander DeConde, contains ninety-five essays. As the editor notes, "The essays explore concepts, themes, large ideas, theories, doctrines, and distinctive policies in the history of American foreign relations" (p. xi). There are commendably few errors of fact in the essays, and only a few are so tendentious that they present a distorted picture. (Among the most striking in this regard are "The Monroe Doctrine," a polemic against its allegedly imperialistic implications that, among other things, does not even discuss the origins of the nonintervention doctrine of 1823, and "Consensus History and Foreign Policy," even more emotionally negative.) There is no comparable work, making the Encyclopedia almost by its mere existence an important contribution. Scholars will not be entirely satisfied with it as a work of reference-it does not purport to be an encyclopedia in the usual sense-but they may well wish to browse in it, even to assign selected essays to graduate students being introduced to the field.

The essayists include most of the best-known men and women-six of the latter-in the field, although some leading figures either were not asked or chose not to contribute, among them Thomas A. Bailey, Gabriel Kolko, Ernest R. May, and Richard W. Leopold. In many, perhaps most, cases, DeConde assigned topics to individuals already identified with them by their earlier writings.

This strategy has obvious advantages, and some of the best essays resulted from its employ. For example, who (unless it were Selig Adler) could write as authoritatively on "Isolationism" as Manfred Jonas? It is not, however, an unalloyed blessing. A few authors appear to have limited their researches to a rereading of their own books. Others, writing on a theme that extends over many decades, give disproportionate attention to the period of their own expertise. Finally, it is by no means clear that, where value judgments must be passed, an advocate is the most appropriate 
essayist. Would not, say, Jerry Israel or Marilyn Young have been more likely to present a balanced discussion of the "Open Door Interpretation" than DeConde's choice, William A. Williams? (Williams's essay consists largely of an aggressively immodest intellectual autobiography, and it hardly does justice to what is the most stimulating, if controversial and often misunderstood, contribution in recent years; reiteration of the word weltanschauung, eighteen times in seven pages, is no substitute for rigorous definition.) Some of the better contributions-for example, Armin Rappaport's "Freedom of the Seas" and Richard E. Welch, Jr.'s "Revolution and Foreign Policy"- are by scholars writing on subjects with which they are not routinely identified.

DeConde asked contributors to discuss subjects ranging in scope from "Realism and Idealism" to "The King Cotton Theory," but the emphasis is on the larger themes. Inevitably, a reviewer will note some omissions at this end of the spectrum. There is no coherent discussion of relations with the third world (although a brief diatribe touching on the subject is in "Foreign Aid"), of interest group influence, of petroleum or multinational corporations or international banking, of American colonial policy (not even in the essay on "Colonialism"), or even of the role of the secretary of state. Inevitably, too, a reviewer will question allocations of space. "The Eisenhower Doctrine" receives nine pages, "The Truman Doctrine" five, and "The Monroe Doctrine" (from 1823 to the Bay of Pigs) a mere twelve. "Neutrality" is alloted only nine pages and "Isolationism" ten, while "Reciprocity" luxuriates in fifteen and "Executive Agreements" are denounced for nineteen. Whether these omissions and imbalances reflect editorial decisions, as opposed to inability to recruit or control contributors, is unclear.

"Even collectively," DeConde states in the preface, "these articles do not attempt to cover chronologically the history of [American] foreign relations" (p. xi). This is certainly true. At the level of detail, and if the index is to be trusted (of this, more anon), no essay mentions the Alaskan boundary, Falaba or Sussex, Alexander McLeod, the Mobile Act, the Schomburgck line, Tecumseh, or the United Fruit Company, and comparable items are only fleetingly considered. At a different level, there is no essay on such things as the diplomacy of the American Revolution, causes of the War of 1812, the Oregon issue, neutrality during either world war, or the Paris peace negotiations of 1919. All of these are tangentially discussed in one or more essays; thus Daniel M. Smith's "The Fourteen Points" and Betty Miller Unterberger's "National Self-Determination," two fine efforts, explore aspects of the Paris negotiations. Except for Smith's essay and those on "The Continental System" and "The King Cotton Theory," none of the essays that are time-bound deal with developments or episodes before World War II. Some of the latter are excellent-Walter LaFeber's "The Truman Doctrine," Gaddis Smith's "The Marshall Plan," and Warren I. Cohen's "The China Lobby," for example-but it is by no 
means clear why others should have been included at the expense of developments before 1941 or 1945.

The presentist emphasis so visible in the topical studies does not, on the whole, distort essays in the other categories in which the contents of the Encyclopedia may be said to fall, for convenience to be called the descriptive, the thematic, and the methodological. The first group, which defines and traces the evolution of such concepts as "Asylum" and "Recognition Policy," is useful almost without exception. Perhaps the two best are Jules Davids's "Extraterritoriality," which makes sense out of a complex subject, and Burton F. Beer's "Protection of American Citizens Abroad," a fine survey of important though workaday functions of diplomats.

Some thematic essays are vast in scope. Adda B. Bozeman is alloted seventeen pages in which to discuss "International Law," one of the longer pieces, but the essay, although often perceptive, is necessarily incomplete and general. In this area, the most successful essays, on the whole, are those that eschew the chronological approach so as to ruminate on themes (Inis L. Claude, Jr., on "International Organization") or to adopt a topical approach (Alfred H. Kelly on "The Constitution and Foreign Policy"). By contrast, the essay on "Presidential Power in Foreign Affairs," precisely because it tells a little bit about every president, seldom grapples with conceptual issues. Even less helpful is the article on "Treaties," little more than a list of major (and some minor) treaties, almost totally lacking in generalizations. (In retrospect, DeConde may regret that he did not commission an essay on the treaty-making power instead.) Articles in this category are, in short, a mixed bag, some very helpful and others pedestrian.

The essays on methodology, approaches, and interpretive frameworks include some of the most stimulating contributions to the Encyclopedia. Two nonhistorians, J. David Singer ("The Behavioral Approach to Diplomatic History") and James N. Rosenau ("Decision-Making Approaches and Theories"), offer useful instruction; Singer may write in too apostolic a tone, but Rosenau is careful to point out weaknesses as well as strengths in the approaches he describes. Athan Theoharis's "Revisionism" is crisp and balanced; emphasis falls upon Harry Elmer Barnes, Charles A. Beard, and William A. Williams, whose approach is made clearer than in the latter's piece on "Open Door Interpretation." Melvin Small writes perceptively about "Public Opinion," weighing (and on the whole downgrading) its impact on policy and pointing to dangers in the use of the slippery term.

The most outstanding essay may well be Joan Hoff Wilson's "Economic Foreign Policy." The title is misleading, since Wilson does not trace trade policy but rather seeks to establish, in a largely theoretical discussion, the importance of economic considerations as compared to those of national interest and ideology. As in her other work (Herbert Hoover aside), Wilson does not allow strong convictions to destroy her balance, 
and the essay is a strong warning against overemphasis of any one set of motivations. "The key consideration," she writes, ". . . is to ascertain the degree to which ideology and economics are mutually reinforcing, rather than to emphasize their incompatibility or consider them as separate, opposite entities" (p. 284). A simple idea, perhaps, but one that is often overlooked.

A project as broad as this Encyclopedia, contributed to by an extensive cross-section of the profession, may tell us some things about the current state of American diplomatic history. The index informs us that Williams is referred to in thirteen essays, more than any other historian save Charles A. Beard, and Williams's intellectual allies are frequently cited. (By contrast, Bemis is mentioned seven times, Dexter Perkins six, and among more recent authors, May and Link three times each.) Citation does not necessarily mean agreement, and some writers refer to Williams's views in order to refute them; the Encyclopedia is by no means a manifesto of revisionism. Still, it is clear that the concept of "open door imperialism" has forced conscientious historians to reconsider their assumptions.

It also appears that we are indeed suffering from a tendency against which Alexander DeConde himself has so eloquently protested. Almost without exception, these essays are discussions solely of American policies, American approaches, and American attitudes. To make a semantic distinction, they are, as the title indicates, essays on the foreign policy of the United States rather than its diplomatic history. Even if this is the purpose, many may be faulted because they pay so little attention to the international setting, leaving American policy seemingly disembodied or appearing to be almost exclusively the product of domestic forces. Insofar as this reflects current professional attitudes, it is to be deplored.

A work of this sort is particularly dependent upon the quality of its index. This one is incomplete, noting, for example, the mention of SackvilleWest but not that of Dupuy de Lome on the same page. It is careless, listing both a "Henry" Feis and Herbert Feis, a Robert "Lancing" and Robert Lansing. It is particularly confused regarding foreign names, so that we have an entry for "Yosuke" but not Matsuoka and "Guzman" rather than Arbenz Guzman. Already incomplete as a work of reference, the Encyclopedia is made even less satisfactory by its index.

In sum, the Encyclopedia of American Foreign Policy is an ambitious, pioneering effort. It contains a number of excellent essays, a larger number of competent ones, and only a few clear failures. It suffers most, perhaps, from the lack of a firmer editorial hand, but anyone who has tried to manage a stable of authors will sympathize with DeConde in this regard. 